\title{
Hubungan Persepsi Mahasiswa Jurusan Sosiologi Fakultas Ilmu Sosial Universitas Negeri Padang Tentang Profesi dengan Minat Menjadi Guru
}

\author{
Khairul Amri ${ }^{1}$, Junaidi Junaidi ${ }^{2}$ \\ ${ }^{1,2}$ Universitas Negeri Padang \\ Email: aalkhairul0@gmail.com,junaidi@fisunp.ac.id
}

\begin{abstract}
Abstrak
Penelitian ini dilatar belakangi adanya kecenderungan awal rendahnya minat mahasiswa pada Prodi Pendidikan Sosiologi FIS UNP untuk menjadi guru, sementara setiap mahasiswa yang memilih prodi keguruan tentu sudah memiliki persespsi sendiri tentang profesi guru, sehingga para mahasiswa tersebut secara mandiri akan konsisten utuk mengembangkan dirinya dalam mencapai tujuannya. Penelitian ini mencoba membuktikan apakah terdapat hubungan persepsi tentang profesi guru dengan minat menjadi guru yang dapat menjadi pemicu para mahasiswa untuk berkembang dikemudian harinya. Penelitian ini menggunakan metode kuantitatif dengan jenis penelitian ex post facto. Teknik pengumpulan data dengan melakukan penyebaran angket secara secara online dengan menggunakan bantuan google form kepada 155 sampel mahasiswa tahun masuk 2016 yang telah menyelesaikan program praktek lapangan kependidikan. Teknik analisis data yang digunakan adalah teknik analisis korelasi product momen. Hasil penelitian menunjukkan bahwa terdapat hubungan yang signifikan antara persepsi mengenai profesi guru dengan minat menjadi guru pada mahasiswa Jurusan Pendidikan Sosiologi Fakultas Ilmu Sosial Universitas Negeri Padang.

Kata kunci : Minat, Profesi Guru, Sosiologi
\end{abstract}

\section{Abstract}

This research is motivated by the initial tendency of low student interest in the Sociology Education Study Program, FIS UNP to become teachers, while every student who chooses the teaching program of course already has his own perception of the teaching profession, so that these students will consistently develop themselves in achieving their goals. This study tries to prove whether there is a relationship between perceptions about the teaching profession and an interest in becoming a teacher that can trigger students to develop in the future. This research uses quantitative methods with ex post facto research. The technique of collecting data is by distributing online questionnaires using the help of Google Forms to 155 samples of 2016 incoming year students who have completed the educational field practice program. The data analysis technique used is the product moment correlation analysis technique. The results showed that there was a significant relationship between perceptions of the teaching profession and interest in becoming a teacher in students of the Department of Sociology Education, Faculty of Social Sciences, Padang State University.

Keywords: Interests, Teaching Profession, Sociology

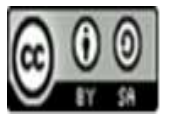




\section{Pendahuluan}

Guru merupakan kompenen utama dalam proses pembelajaran. Tanpa guru kegiatan pembelajaran akan sulit untuk dilaksanakan. Meskipun fasilitas belajar lengkap, jika tidak ada guru profesional yang menjalankan proses belajar mengajar maka pelaksanaan pembelajaran tidak akan berjalan lancar. Oleh karena itu, pada setiap kegiatan pembelajaran keberadaan guru adalah syarat utama, sehingga itu perlu mempersiapkan calon guru yang memiliki kompetensi yang sesuai.

Calon guru harus memiliki jenjang pendidikan yang sesuai dengan bidang ilmunya, memiliki kualifikasi tertentu dan memenuhi kompetensi guru. Oleh karena itu sebelum calon mahasiswa memilih jurusan keguruan, sebaiknya mereka memiliki minat untuk menjadi seorang guru. Menurut Hurlock (Elizabeth, 2004), minat merupakan sumber motivasi yang mendorong orang untuk melakukan apa yang mereka inginkan. Bila mereka bebas memilih dan menilai bahwa sesuatu akan bermanfaat maka akan mendatangkan kepuasan, ketika kepuasan menurun maka minatnya juga akan menurun, sehingga minat tidak bersifat permanen tetapi minat bersifat sementara atau dapat berubah-rubah (Khairani, 2014). Minat mengandung beberapa ciri-ciri, yaitu adanya pemusatan perhatian, perasaan dan pikiran dari subyek ketertarikan, adanya perasaan senang terhadap obyek yang menjadi sasaran, berikutnya adanya kemauan atau kecenderungan pada diri subjek untuk melakukan kegiatan dengan mencapai tujuan (Khairani, 2014).

Salah satu program studi yang menghasilkan guru Sosiologi adalah Prodi Pendidikan Sosiologi FIS Universitas Negeri Padang. Untuk mengetahui minat mahasiswa pada prodi ini menjadi guru, peneliti menyebarkan angket kepada mahasiswa yang sudah lulus menjalankan program Praktik Lapangan Kependidikan (PLK) yaitu sebanyak 155 orang. Berikut data yang diperoleh dari penyebaran angket minat mahasiswa.

Tabel 1. Minat Menjadi Guru Pada Mahasiswa Prodi Pendidikan Sosiologi Tahun Masuk 2016

\begin{tabular}{clcc}
\hline No & \multicolumn{1}{c}{ Deskriptor Minat Menjadi Guru } & Ya & \% \\
\hline 1. & $\begin{array}{l}\text { Profesi guru menarik perhatian saya dari berbagai profesi } \\
\text { yang ada }\end{array}$ & 85 & $54,8 \%$ \\
\hline 2. & $\begin{array}{l}\text { Saya merasa bahwa menjadi guru adalah profesi yang cocok } \\
\text { untuk saya }\end{array}$ & 86 & $55,4 \%$ \\
\hline 3. & $\begin{array}{l}\text { Saya sering memikirkan bagaimana kelak saya menjadi } \\
\text { seorang guru }\end{array}$ & 74 & $47,7 \%$ \\
\hline 4. & $\begin{array}{l}\text { Saya senang ketika melakukan Praktek Lapangan } \\
\text { Kependidikan di sekolah }\end{array}$ & 77 & $49,6 \%$ \\
\hline 5. & Saya berusaha untuk mencapai tujuan untuk menjadi guru. & 76 & $49,03 \%$ \\
\hline & Rata-Rata & $51,3 \%$ \\
\hline
\end{tabular}

Sumber: Data Penelitian (2021)

Berdasarkan data di atas dapat dilihat 51,3\% yang menyatakan berminat menjadi guru. Data ini juga tidak berbanding lurus dengan tingkat peminat Prodi Pendidikan Sosiologi FIS UNP, ternyata dengan peminat prodi yang tinggi belum diiringi dengan tingginya minat mereka menjadi guru. yang tinggi pula untuk jadi guru. Hal ini akan menjadi masalah apabila mereka kelak bekerja pada instasi keguruan namun tidak disertai dengan minat menjadi guru tentu akan akan berdampak pada sulitnya mewujudkan proses belajar yang baik dan sukarnya mencapai tujuan pembelajaran secara maksimal. 
Suryabrata juga menyatakan "minat adalah pemusatan tenaga psikis yang tertuju pada suatu obyek serta banyak sedikitnya kekuatan yang menyertai sesuatu aktivitas yang dilakukan." (Suryabrata, 2002). Kemudian Suryobroto juga mendefinisikan "minat sebagai suatu pemusatan perhatian yang tidak disengaja yang terlahir dengan penuh kemauan dan tergantung dari bakat dan lingkungan." (Suryobrota, 2002). Pemusatan perhatian menurut pendapat tersebut merupakan tanda seseorang yang mempunyai minat terhadap sesuatu yang muncul dengan tidak sengaja yang menyertai sesuatu aktivitas tertentu. Dari pendapat para ahli tersebut dapat diasumsikan bahwa timbulnya minat seseorang itu disebabkan oleh beberapa faktor penting yaitu persepsi, rasa tertarik atau rasa senang, faktor perhatian dan kebutuhan.

Menurut (Walgito, 2010) persepsi adalah proses pengorganisasian, penginterpretasian terhadap stimulus yang diterima oleh individu sehingga merupakan sesuatu yang berarti dan merupakan aktivitas yang terintegrasi dalam diri individu. Individu dapat menyadari tentang keadaan lingkungan yang ada disekitarnya dan juga tentang keadaan diri individu yang bersangkutan.

Minat mahasiswa calon guru tidak dapat diketahui atau diukur secara langsung, namun harus melalui faktor-faktor yang dapat digunakan untuk mengungkap minat seseorang terhadap sesuatu. Karena minat tidak dapat diukur secara langsung maka unsur-unsur atau faktor yang menyebabkan timbulnya minat tersebut perlu ditelusuri untuk mengungkap minat seseorang. Dalam faktor ini disusun pertanyaan yang berguna untuk mengungkap minat seseorang terhadap suatu kegiatan. Salah satunya dalah melalui persepsi calon guru terhadap profesi guru.

Penelitian tentang hubungan antara minat dan persepsi menjadi guru ini sudah pernah diteliti oleh peneliti sebelumnya. Pertama, (Kurniawan, 2020) mengatakan bahwa terdapat hubungan positif yang signifikan persepsi mahasiswa tentang profesi guru dengan minat menjadi guru pada mahasiswa program studi Pendidikan Akutansi Fakultas Keguruan Dan Ilmu Pendidikan Universitas Sebelas Maret. Kedua, penelitian yang dilakukan oleh Veronika Retno Ima Setyaninggrum. Hasil dari penelitiannya terdapat hubungan antara persepsi mahasiswa tentang profesi guru dan dukungan keluarga dengan minat menjadi guru. Studi kasus pada mahasiswa Program Studi Pendidikan Ekonomi BKK Pendidikan Ekonomi dan Pendidikan Akutansi angkatan 2016 Fakultas Keguruan dan Ilmu Pendidikan, Universitas Sanata Dharma Yogyakarta.(Veronica Retno Setyaningrum, 2019).

Berdasarkan latar belakang diatas, penulis tertarik untuk melakukan penelitian dengan judul "Hubungan Persepsi Mahasiswa tentang Profesi Guru dengan Minat menjadi Guru di Jurusan Pendidikan Sosiologi Fakultas Ilmu Sosial Universitas Negeri Padang".

\section{Metode Penelitian}

Metode yang digunakan dalam penelitian ini adalah metode kuantitatif. Metode penelitian kuantitatif adalah metode yang menggunakan teknik pengumpulan dan analisis data melalui analisis data statistik dan dapat diambil secara random serta berlandaskan pada filsafat positivistik (Sugiyono, 2017). Jenis penelitian ini adalah ex post facto yang merupakan penyelidikan empiris yang sistematis, ilmuan tidak mengendalikan variabel bebas secara langsung karena eksistensi dari variabel tersebut telah terjadi, atau karena pada dasarnya variabel tersebut tidak dimanipulasi (Jannah \& Sylvia, 2020). Penelitian ini dilakukan pada mahasiswa Prodi Pendidikan Sosiologi FIS UNP, khususnya pada mahasiswa tahun masuk 2016, dan dilaksanakan pada semester Januari-Juni 2021.

Populasi dalam penelitian ini adalah seluruh mahasiswa Jurusan Sosiologi Fakultas Ilmu Sosial Universitas Negeri Padang yang aktif kuliah pada semester Januari-Juni 2021. Dalam penelitian ini penulis memutuskan untuk mengambil sampel mahasiswa tahun masuk 2016 yang berjumlah 155 orang dengan alasan mahasiswa ini telah selesai mengikuti program PLK. Jenis data yang penulis kumpulkan ialah data primer yaitu data yang diperoleh oleh peneliti melalui

Jurnal Sikola: Jurnal Kajian Pendidikan dan Pembelajaran Vol. 3, No. 2, Th. 2021 
angket yang diisi langsung oleh mahasiswa. Dalam hal ini angket berisikan pernyataan yang sesuai dengan variabel persepsi dan minat menjadi guru.

Analisis data dalam penelitian ini dilakukan melalui dua tahapan. Tahap pertama, yaitu uji persyaratan dilakukan menggunakan uji normalitas dan uji homogenitas data. Uji normalitas data dengan menggunakan uji lilliefors pada signifikan 0,05 untuk mengetahui sebaran data berdistribusi normal atau tidak. Standar pengujiannya adalah jika $\mathrm{L}_{0}$ yang diperoleh dari data observasi melebihi Lt, maka $\mathrm{H}_{0}$ ditolak, begitu pula sebaliknya. (Widiyanto, 2013).

Tahap kedua, yaitu uji hipotesis analisis korelasi product moment, bertujuan untuk mengetahui hubungan antara variabel $\mathrm{X}$ dan variabel $\mathrm{Y}$. Dasar dalam pengambilan keputusan analisis korelasi product moment dengan membandingkan hasil perhitungan perbandingan nilai $\mathrm{R}_{\text {hitung }}$ dengan $\mathrm{R}_{\text {tabel. }}$. Jika nilai $\mathrm{R}_{\text {hitung }}>\mathrm{R}_{\text {tabel }}$ maka ada kontribusi variabel bebas (X) terhadap variabel terikat $(Y)$ atau hipotesis diterima, sedangkan jika nilai $R_{\text {hitung }}<R_{\text {tabel }}$ maka tidak ada kontribusi variabel bebas $(\mathrm{X})$ terhadap variabel terikat $(\mathrm{Y})$ atau hipotesis ditolak.

\section{Hasil Penelitian dan Pembahasan}

\section{Hasil Penelitian}

Dalam penelitian ini terdapat dua variabel yang diuji berdasarkan hasil skor angket yang didapatkan. Variabel tersebut adalah persepsi mengenai profesi guru sebagai variabel bebas (X) dan minat menjadi guru sebagai variabel terikat (Y). Angket yang peneliti kembangkan terdiri dari 20 pernyataan untuk setiap variabelnya. Deskripsi mengenai data rata-rata dari skor angket dari kedua variabel tersebut dapat dilihat pada tabel di bawah ini.

\section{Tabel 2. Rata-rata Skor Angket Persepsi Mengenai Profesi Guru dan Minat Menjadi Guru}

\begin{tabular}{lcccc}
\hline \multicolumn{1}{c}{ Variabel } & N & Skor Tertinggi & Skor Minimal & $\begin{array}{c}\text { Skor rata- } \\
\text { rata }\end{array}$ \\
\hline Persepsi mengenai profesi guru & 155 & 78 & 96 & 87 \\
\hline Minat menjadi guru & 155 & 75 & 95 & 85 \\
\hline
\end{tabular}

Sumber: Data Penelitian (2021)

Berdasarkan tabel di atas dapat dilihat bahwa pada variabel X skor terendah 78 dan skor tertinggi 96 dan nilai rata-rata 87, sementara pada variabel $\mathrm{Y}$ skor terendah 75 dan skor tertinggi 95 dengan rata-rata 85 . Hasil ini memperlihatkan rata-rata yang cukup baik, pada variabel persepsi mengenai profesi guru maupun minat menjadi guru. Selanjutnya penulis akan medeskripsikan hasil angket masing-masing variabel.

Adapun menurut Walgito (Walgito, 2001), persepsi memiliki indikator-indikator sebagai berikut: (a) Penyerapan terhadap rangsang atau objek dari luar individu. Rangsangan atau objek tertentu yang diserap atau diterima oleh panca indera, baik penglihatan, pendengaran, peraba, pencium, dan pengecap secara sendiri-sendiri maupun bersama-sama. Dari hasil penyerapan atau penerimaan oleh alat-alat indera tersebut akan mendapatkan gambaran, tanggapan, atau kesan di dalam otak; (b) Pengertian dan pemahaman. Setelah terjadi gambaran atau kesan di dalam otak, maka gambaran tersebut diorganisir, digolong-golongkan (diklasifikasi), dibandingkan, diinterprestasi, sehingga terbentuk pengertian atau pemahaman; (c) Penilaian atau evaluasi. Setelah terbentuk pemahaman, terjadilah penilaian dari individu. Individu membandingkan pemahaman yang baru diperoleh tersebut dengan kriteria atau norma yang dimiliki individu secara subjektif. Penilaian dari individu berbeda-beda meskipun objeknya sama. Oleh karena itu persepsi bersifat individual. Berdasarkan penjelasan di atas, penulis mengembangkan angket yang terdiri dari 3 indikator, yaitu penerimaan, pemahaman dan evaluasi. Berikut deskripsi data angket mengenai Persepsi Mahasiswa terhadap Profesi Guru.

Jurnal Sikola: Jurnal Kajian Pendidikan dan Pembelajaran Vol. 3, No. 2, Th. 2021 
Khairul Amri, Junaidi Junaidi Hubungan Persepsi Mahasiswa Tentang Profesi Guru Dengan Minat menjadi Guru di Jurusan Sosiologi Fakultas Ilmu Sosial Universitas Negeri Padang

Tabel 3. Deskripsi Angket Persepsi Mahasiswa Terhadap Profesi Guru

\begin{tabular}{clcl}
\hline No & \multicolumn{1}{c}{ Indikator } & Rata-rata & Kategori \\
\hline 1. & $\begin{array}{l}\text { Melakukan penerimaan terhadap tugas dan } \\
\text { tanggung jawab sebagai guru }\end{array}$ & 92 & Sangat Baik \\
\hline 2. & Memahami tantangan profesi sebagai guru & 88 & Sangat Baik \\
\hline 3. & Melakukan telaah terhadap profesi guru & 81 & Baik \\
\hline \multicolumn{4}{c}{ Rata-rata } \\
\hline
\end{tabular}

Sumber: Data Penelitian (2021)

Minat Menjadi Guru (Y) adalah kesediaan jiwa atau keinginan seseorang untuk menekuni suatu profesi guru, dimana profesi guru ini memiliki peranan dan kompetensi profesional serta memerlukan keahlian khusus sebagai seorang guru. Minat menjadi guru mempunyai indikatorindikator sebagai berikut: (1). Persepsi Mahasiswa terhadap profesi guru; (2) Sikap Mahasiswa apabila menjadi guru; (3) Wawasan terhadap bidang kependidikan. Berikut deskripsi data angket mengenai minat mahasiswa menjadi guru.

Tabel 4. Deskripsi Angket Minat Mahasiswa Menjadi Guru

\begin{tabular}{clcc}
\hline No & \multicolumn{1}{c}{ Indikator } & Rata-rata & Kategori \\
\hline 1. & Menyukai profesi guru & 89 & Sangat Tinggi \\
\hline 2. & $\begin{array}{l}\text { Memiliki kecenderungan untuk memperhatikan cara } \\
\text { guru dalam menjalankan tugasnya }\end{array}$ & 87 & Sangat Tinggi \\
\hline 3. & Memiliki kebanggaan ketika mengajar & 89 & Sangat Tinggi \\
\hline 4. & $\begin{array}{l}\text { Berpartisipasi saat program PLK dalam setiap kgiatan } \\
\text { yang berhubungan dengan profesi guru }\end{array}$ & 82 & Tinggi \\
\hline 5. & $\begin{array}{l}\text { Mencari tahu lebih dalam mengenai pengebangan diri } \\
\text { untuk menjadi guru yang baik }\end{array}$ & 78 & Tinggi \\
\hline Rata-rata & 85 & \\
\hline
\end{tabular}

Sumber: Data Penelitian (2021)

Hasil penelitian menunjukkan bahwa minat menjadi guru mahasiswa Prodi Pendidikan Sosiologi FIS UNP angkatan 2016 dalam kategori sangat tinggi dengan rata-rata 85. Apabila minat mahasiswa untuk menjadi guru terus dipupuk, maka minat tersebut lama kelamaan akan semakin tinggi, hal ini sesuai dengan pendapatnya Slameto (Slameto, 2010) bahwa minat pada dasarnya adalah penerimaan akan suatu hubungan antara diri sendiri dengan sesuatu diluar diri. Semakin kuat atau dekat hubungan tersebut semakin besar minat. Minat menjadi guru mempunyai dua unsur yang dapat mempengaruhi tinggi rendahnya minat, yaitu unsur kognisi terdiri dari persepsi mahasiswa terhadap profesi guru dan sikap mahasiswa apabila menjadi guru. Sedangkan unsur yang kedua yaitu konasi, unsur konasi ini meliputi wawasan mahasiswa terhadap bidang keguruan dan keakuntansian. Apabila ketiga hal ini berjalan secara bersamasama dan saling mendukung, maka minat menjadi guru seseorang akan tumbuh dengan baik. Sebaliknya, apabila ketiga hal di atas tidak saling mendukung maka kemungkinan besar minat seseorang untuk menjadi guru akan rendah. Dalam hal ini perlu ada perhatian dari berbagai pihak, sehingga mahasiswa yang berada pada program studi pendidikan akan termotivasi untuk lebih meningkatkan minatnya untuk menjadi guru. 
Khairul Amri, Junaidi Junaidi

Hubungan Persepsi Mahasiswa Tentang Profesi Guru Dengan Minat menjadi Guru di Jurusan Sosiologi Fakultas Ilmu Sosial Universitas Negeri Padang

\section{Uji Persyaratan Penelitian}

\section{Uji Normalitas}

Uji normalitas data skor angket persepsi mengenai profesi guru dan minat menjadi guru dengan uji kolmogorov-smirnov, menggunakan SPSS 25. Pengujian ini dilakukan untuk melihat sebaran data persepsi mengenai profesi guru (varibel $\mathrm{X}$ ) dan minat menjadi guru (Y) berdistribusi normal atau tidak. Hasil perhitungannya dapat dilihat pada tabel berikut ini.

Tabel 5. Rangkuman Hasil Uji Normalitas

\begin{tabular}{llcccc}
\hline No & Variabel & N & $\begin{array}{c}\text { Harga Statistik } \\
\text { untuk Kolmogorov- } \\
\text { Smirnov }\end{array}$ & $\begin{array}{c}\text { Sig atau } \\
\text { P-Value }\end{array}$ & Kesimpulan \\
\hline 1 & $\begin{array}{l}\text { Persepsi mengenai profesi } \\
\text { guru (X) }\end{array}$ & 155 & 0,0147 & 0,189 & Normal \\
\hline 2 & Minat menjadi guru (Y) & \multicolumn{1}{c}{155} & 0,014 & 0,167 & Normal \\
\hline \multicolumn{5}{r}{ Sumber: Data Penelitian (2021) } \\
\hline
\end{tabular}

Berdasarkan tabel di atas, di peroleh harga statistik untuk kolmogorov-smirnov varibel $\mathrm{X}$ sebesar 0,0147 dan sig atau $\mathrm{p}$-value $=0,189>0,05, \mathrm{H}_{0}$ diterima, untuk harga statsitik variabel $\mathrm{Y}$ kolmogorov-smirnov 0,014 dan sig atau p-value 0,167 >0,05, maka $\mathrm{H}_{0}$ diterima. Dengan pernyataan tersebut berarti memberi kesimpulan yaitu semua data berdistribusi normal.

\section{Uji Hipotesis}

Dalam pengujian hipotesis penelitian ini digunakan teknik analisis korelasi product moment. Korelasi product moment adalah teknik statistik untuk mengetahui sejauh mana hubungan antar variabel. Analisis korelasi product moment digunakan hanya untuk satu variabel bebas (independent) dan satu variabel terikat (dependent). Tujuan penerapan metode ini adalah untuk meramalkan atau memprediksi besaran nilai variabel terikat (dependent) yang dipengaruhi oleh variabel bebas (independent) (Siregar, 2017). Pada tabel berikut hasil analisis data hipotesis penelitian.

Tabel 6. Hasil Analisis Hipotesis

\begin{tabular}{ccc}
\hline $\mathbf{R}_{\text {hitung }}$ & $\mathbf{R}_{\text {tabel }}$ & Kesimpulan \\
\hline $\mathbf{0 , 1 6 4}$ & $\mathbf{0 , 1 5 6 7}$ & Terdapat hubungan \\
\hline
\end{tabular}

Sumber: Data Penelitian (2021)

Berdasarkan tabel di atas, terdapat hubungan antara persepsi mahasiswa tentang profesi guru dengan minat menjadi guru pada Prodi Pendidikan Sosiologi Fakultas Ilmu Sosial Universitas Negeri Padang, karena berdasarkan perbandingan nilai $r_{\text {hitung }}(0,165)>r_{\text {tabel }}(1,1567)$, maka dapat disimpulkan bahwa hipotesis diterima.

\section{Pembahasan}

Pembahasan ini merupakan jawaban dari permasalahan yang penulis ajukan, sehingga dapat diketahui hubungan antara persepsi mengenai profesi guru dengan minat menjadi guru pada mahasiswa Prodi Pendidikan Sosiologi Fakultas Ilmu Sosial Universitas Negeri Padang. Berdasarkan perbandingan nilai $r_{\text {hitung }}(0,165)>r_{\text {tabel }}(1,1567)$, dapat disimpulkan bahwa hipotesis diterima. Hasil penelitian yang diperoleh dari perhitungan tersebut sesuai dengan penelitian yang telah dikemukakan oleh Devi Yulianingsih yang berjudul Kesiapan Menjadi Guru Ditinjau Dari Sikap Keguruan Dan Persepsi Mahasiswa Tentang Profesi Guru. Penelitian ini dilakukan pada mahasiswa Pendidikan Akutansi angkatan 2014/2015 Fakultas Keguruan dan Ilmu Pendidikan Universitas Muhammadiyah Surakarta. Hasil penelitian menunjukkan bahwa ada pengaruh 
positif yang signifikan persepsi mahasiswa tentang profesi guru terhadap kesiapan menjadi guru pada pendidikan akutansi angkatan 2014/2015 Fakultas Keguruan dan Ilmu Pendidikan Universitas Muhammadiyah Surakarta. Hal ini berdasarkan hasil regresi linear berganda variable persepsi mahasiswa tentang profesi guru diperoleh $t_{\text {hitung }}>t_{\text {tabe }} 1$ yaitu $2.210>1,980$ dan nilai signifikan $<0,05$ yaitu 0,029 dengan sumbangan relatif sebesar $22 \%$ dan sumbangan efektif $7,4 \%$. Hasil penelitian manunjukkan adanya pengaruh positif yang signifikan variabel persepsi mahasiswa tentang profesi guru terhadap kesiapan menjadi guru pada mahasiswa Pendidikan Akutansi angkatan 2014/2015 Fakultas Keguruan dan Ilmu Pendidikan Universitas Muhammadiyah Surakarta (Devi \& Wafrour, 2018). Berdasarkan kesimpulan tersebut dapat dikatakan bahwa semakin baik persepsi mahasiswa tentang profesi guru akan semakin tinggi kesiapan menjadi guru. Sebaliknya semakin rendah persepsi mahasiswa tentang profesi guru, maka semakin rendah pula kesiapan menjadi guru.

Persamaan dari penelitian relevan dengan penelitian ini adalah sama-sama meneliti tentang persepsi profesi guru dengan minat menjadi guru. Perbedaan dari penelitian ini, dimana tempat untuk penelitian relevan pada mahasiswa Pendidikan Akutansi angkatan 2014/2015 Fakultas Keguruan dan Ilmu Pendidikan Universitas Muhammadiyah Surakarta sedangkan penelitian ini pada mahasiswa Pendidikan Sosiologi angkatan 2016 dan 2017 Fakultas Ilmu Sosial Universitas Negeri Padang.

Alfiyyah Nurlaili Sukma menyatakan bahwa persepsi mengenai profesi guru memiliki kontribusi pengaruh sebesar $48,8 \%$ terhadap minat menjadi guru pada mahasiswa. (Sukma, A. N., Karlina, E., 2020). Hasil yang diperoleh kedua faktor berpengaruh signifikan secara parsial maupun simultan dan memiliki kontribusi pengaruh sebesar 48,8\%. Angka kontribusi efektif ini jauh berbeda karena memang bukan kontribusi terhadap keputusan pemilihan program studi melainkan terhadap minat untuk memilih. Pada akhirnya minat untuk memilih juga akan berkontribusi dalam keputusan pemilihan program studi, namun kontribusinya tentu tidak akan sama karena masih banyak faktor-faktor lain.

Persepsi seseorang pada suatu hal pasti berbeda-beda, hal ini dibedakan oleh beberapa faktor yang mempengaruhi persepsi mahasiswa. Adapun menurut Walgito faktor-faktor yang mendukung terjadinya persepsi adalah: 1) Ketersediaan informasi sebelumnya, tidak adanya informasi ketika seseorang menerima stimulus yang baru bagi dirinya akan menyebabkan kekacauan dalam mempersepsi. Informasi juga dapat menjadi acuan untuk mempersepsikan sesuatu. 2) Kebutuhan Kebutuhan cenderung akan membuat seseorang mempersepsikan sesuatu. Contoh sederhana, seseorang yang bercita-cita ingin menjadi guru akan lebih bersemangat untuk mencari informasi tentang profesi guru. 3) Pengalaman masa lalu akan mempengaruhi seseorang mempersepikan sesuatu. Contohnya, ketika seseorang memiliki pengalaman yang baik maka dia akan cenderung mempersepsikan bahwa itu adalah pengalaman yang tidak dapat dilupakan. 4) Emosi akan mempengaruhi seseorang dalam menerima dan mengolah informasi, karena sebagian perhatiannya adalah emosinya tersebut. 5) Impresi Stimulus yang menonjol, akan lebih dahulu mempengaruhi persepsi seseorang. Gambar yang besar, warna yang kontras, dan suara yang keras akan lebih menarik seseorang untuk diperhatikan dan menjadi fokus dari persepsinya. 6) Konteks Konteks dapat ditentukan secara sosial, budaya, atau lingkungan fisik. Konteks memberikan dasar yang sangat menentukan suatu objek yang dipandang. Berdasarkan pendapat di atas, maka dapat disimpulkan bahwa faktorfaktor yang mempengaruhi persepsi ialah ketersediaan informasi sebelumnya, kebutuhan, pengalaman masa lalu, emosi, impresi dan konteks.

Hasil penelitian ini mendukung penelitian terdahulu, yaitu minat menjadi guru dipengaruhi oleh penerimaan, pemahaman dan evaluasi subjek persepsi terhadap profesi guru. Dalam penelitian ini pemahaman yang baik pada dasarnya mengacu pada pengetahuan mahasiswa tentang profesi guru dan ekspektasi mereka terhadap profesi guru tersebut. Oleh karena itu, pemahaman yang baik tentang profesi guru akan membangkitkan minat belajar mata

Jurnal Sikola: Jurnal Kajian Pendidikan dan Pembelajaran Vol. 3, No. 2, Th. 2021 
Khairul Amri, Junaidi Junaidi

Hubungan Persepsi Mahasiswa Tentang Profesi Guru Dengan Minat menjadi Guru di Jurusan Sosiologi Fakultas Ilmu Sosial Universitas Negeri Padang

kuliah pendidikan sosiologi, yang pada akhirnya akan mendorong mereka untuk memutuskan untuk memilih suatu mata kuliah.

\section{Kesimpulan}

Berdasarkan hasil penelitian yang telah dilakukan maka dapat diambil kesimpulan bahwa Hubungan Persepsi Mahasiswa Tentang Profesi Guru dengan Minat Menjadi Guru di Prodi Pendidikan Sosiologi Fakultas Ilmu Sosial Universitas Negeri Padang tahun masuk 2016 dimana variabel Persepsi Tentang Profesi Guru (X) dan Minat Menjadi Guru (Y) mempunyai hubungan yang positif, Dari hasil analisis diperoleh $R_{\text {hit }}=0,164$ dan $R_{\text {tabel }}=0,1567$. Uji hipotesis membuktikan terdapat hubungan antara persepsi mahasiswa tentang profesi guru dengan minat menjadi guru pada Prodi Pendidikan Sosiologi Fakultas Ilmu Sosial Universitas Negeri Padang Berdasarkan kesimpulan diatas terdapat beberapa saran diantaranya meningkatkan penerimaan, pemahaman dan melakukan penilaian terhadap profesi guru agar dapat meningkatkan minat mereka terhadap profesi guru dan kompetensinya, sebaliknya jika persepsi tentang profesi guru rendah maka minat menjadi guru juga rendah.

\section{Daftar Pustaka}

Devi, Y \& Wafrour, R. (2018). Kesiapan Menjadi Guru Ditinjau Dari Sikap Keguruan Dan Persepsi Mahasiswa Tentang Profesi Guru Pada Mahasiswa Pendidikan Akuntansi Angkatan 2014/2015. Universitas Muhammadiyah Surakarta.

Elizabeth, B. H. (2004). Psikologi Perkembangan. Jakarta: Gelora Aksara Pratama.

Jannah, I. N., \& Sylvia, I. (2020). Hubungan Kelompok Teman Sebaya terhadap Gaya Hidup $\begin{array}{lllll}\text { Hedonisme pada Mahasiswa. Jurnal Perspektif, } & 3(1),\end{array}$ https://doi.org/10.24036/perspektif.v3i1.199

Khairani, M. (2014). Psikologi Belajar. Yogyakarta: Aswaja Pressindo.

Kurniawan, R. A. (2020). Hubungan Persepsi Mahasiswa Tentang Profesi Guru dan Lingkungan Keluarga Dengan Minat Menjadi Guru Pada Mahasiswa Progam Studi Pendidikan Akuntansi Fakultas Keguruan dan Ilmu Pendidikan Universitas Sebelas Maret. Malaysian Palm Oil Council (MPOC).

Siregar, S. (2017). Statistika Terapan Untuk Perguruan Tinggi (2nd ed.). Jakarta: Kencana.

Slameto, S. (2010). Belajar dan Faktor-faktor yang Mempengaruhinya. Jakata: Kencana

Sugiyono, S. (2017). Metode Penelitian Kuantitatif, Kualitatif, san Kombinasi (Mixed Methods) (Sutopo, Ed.). Bandung: CV. Alfabeta.

Sukma, A. N., Karlina, E., \& P. (2020). Pengaruh Persepsi Profesi Guru Terhadap Minat Menjadi Guru Pada Mahasiswa Pendidikan Ekonomi Universitas Indraprasta PGR. Research and Development Journal of Education, 1(1), 110-116.

Suryabrata, S. (2002). Psikologi Pendidikan. Jakarta: Raja Grafindo Persada.

Veronica, R.S. (2019). Hubungan Persepsi Mahasiswa Tentang Profesi Guru dan Dukungan Keluarga dengan Minat Menjadi Guru. Universitas Sanata Dharma Yogyakarta.

Walgito, B. (2001). Psikologi Sosial. Yogyakarta: Andi Offset.

Walgito, B. (2010). Pengantar Psikologi Umum. Yogyakarta: C.V Andi.

Widiyanto, M. A. (2013). Statistika Terapan: Konsep \& Aplikasi SPSS dalam Penelitian Bidang Pendidikan, Psikologi \& Ilmu Sosial Lainnya. jakarta: Elex Media Komputindo. 